\title{
Entomophagy: A Narrative Review on Nutritional Value, Safety, Cultural Acceptance and A Focus on the Role of Food Neophobia in Italy
}

\author{
Elisabetta Toti ${ }^{1, *(1)}$, Luca Massaro ${ }^{1}$, Aisha Kais ${ }^{1}$, Paola Aiello ${ }^{2,3}$, Maura Palmery ${ }^{2}$ \\ and Ilaria Peluso ${ }^{1}$ (D) \\ 1 Research Centre for Food and Nutrition, Council for Agricultural Research and Economics (CREA-AN), \\ 00142 Rome, Italy; msluca96@gmail.com (L.M.); aishakais@libero.it (A.K.); ilaria.peluso@crea.gov.it (I.P.) \\ 2 Department of Physiology and Pharmacology "V. Erspamer", Sapienza University of Rome, \\ 00185 Rome, Italy; paola.aiello@uniroma1.it (P.A.); maura.palmery@uniroma1.it (M.P.) \\ 3 Faculty of Health Sciences, Universidad Católica San Antonio de Murcia, Murcia (UCAM), \\ 30107 Murcia, Spain \\ * Correspondence: elisabetta.toti@crea.gov.it; Tel.: +39-06-51494624
}

Received: 24 April 2020; Accepted: 1 June 2020; Published: 3 June 2020

\begin{abstract}
In recent years, the consumption of insects, or entomophagy, has produced an increasing interest amongst scientists and ecologists as a potential source of animal protein. Eating insects is also interesting in terms of low greenhouse gas emissions and low land use. In contrast to tropical countries, where most of the 2000 edible insect species are traditionally consumed, the concept of eating insects is still new to Western culture and diet. Culture and eating habits exert a great influence on what is considered edible in the Mediterranean area, especially in Italy, where the preservation of culinary traditions is a predominant factor affecting dietary behaviour. The purpose of this narrative paper is to provide an overview of the main topics related to entomophagy. The introduction presents some information about the nutrient content and safety aspects, the second part summarises the cultural acceptance of insect in the world, while the role of food neophobia on the intention to consume insects in Italy is focused on in part three. The discussion displays important viewpoints of previously published studies and based on these perspectives it can be concluded that the Italian diet is still clearly influenced by local tradition. In conclusion, in order to introduce insects into the Italian diet, psychological motivation has to be enhanced.
\end{abstract}

Keywords: consumers' acceptance; food safety; food attitude; edible insects; Italy

\section{Introduction}

Edible insects have been suggested as a source of proteins, amino acids, essential fatty acids, fibre and micronutrients [1,2]. Insects are environmentally friendly, as they can recycle waste, require little food and water for their growth, and have a rapid growth rate [3,4]. For all these reasons, in recent years, entomophagy has reached global attention and currently the potential use of insects as a new source of food for humans appears extremely interesting [5]. It has been suggested that insects could be a promising alternative source of animal protein with a reduced environmental impact [6,7], however, further research is needed to verify any possible risk to human health. Legislation on production, transformation and commercialization aspects have been previously reported by other authors in some review articles [5,8,9]. In Italy, an informative note, published on 8 January 2018 by the Italian Health Ministry, clarified that insects belong to a group of novel foods, which have not been authorized yet [10]. The absence of Italian legislative authorization and the precautionary principle asserted in the Official Journal of the European Union (EU Regulation 2015/2283) are not the only 
factors that explain the attitude of Italian consumers towards entomophagous practices [11]. In fact, psychological, sociological and anthropological factors play an important role in the choice of insect products by Italian consumers [12]. We aimed to make an overview on some aspects of entomophagy and in particular, discuss the existing aversion amongst Mediterranean consumers, with particular reference to the Italian population, in which complex food decision-making, due to attachment to tradition, has been identified [2].

\subsection{Nutritional Value}

Providing a complete worldwide picture on the edible insect species is very complex because there is limited information on species eaten as part of traditional diets in different geographical areas. Out of the millions of insect species living on Earth, about 2000 are considered edible and their use varies between regions and cultures [13,14]. According to Jongema (2017) [14], most of the insects consumed belong to the order of Coleoptera (e.g., beetles), followed by Lepidoptera (e.g., caterpillars), Hymenopterans (e.g., bees, wasps and ants), Orthoptera (e.g., grasshoppers, locusts and crickets), and lastly, Hemiptera (e.g., cicadas, leafhoppers, cochineals and bugs). Studies on the nutritional composition of edible insects should meet internationally recognized standards. The variation in nutrient composition is due to different analytical methodologies, the heterogeneity existing between insects from different environments and different rearing $[15,16]$ and storage conditions [17]. The international network of food data systems (FAO INFOODS) has recently published a database on food composition [18] and in version 4.0 a total of 471 edible insects, with different methods of preparation, have been included [19]. Energy, macronutrient, micronutrient and fibre content, from the FAO INFOODS database, are summarized in Table 1.

Table 1. Nutrient composition of some edible insects (per $100 \mathrm{~g}$ edible portion on fresh weight).

\begin{tabular}{lcccccc}
\hline & Coleoptera & Lepidoptera & Hymenoptera & Orthoptera & Hemiptera & Isoptera \\
\hline Energy (kcal) & $78-155$ & $358-361$ & $79-184$ & $89-227$ & $63-165$ & $93-535$ \\
\hline Protein (g) & $13-21$ & $49-55$ & $7-14$ & $13-68$ & $19-20$ & $21-21$ \\
\hline Fat (g) & $1-19$ & $4-22$ & $3-13$ & $1-43$ & $2-57$ & $2-42$ \\
\hline CHO (g) & $1-3$ & $12-18$ & $5-6$ & $1-5$ & $3-8$ & $20-21$ \\
\hline Fiber (g) & $5-7$ & $4-15$ & $1-3$ & $2-10$ & $4-5$ & $5-6$ \\
\hline Fe(mg) & $0.3-24$ & $0.03-109$ & $3-103$ & $0.1-42$ & $0.4-29$ & $0.1-31$ \\
\hline Zn (mg) & $5-6$ & $2-11$ & $4-15$ & $4-13$ & $4-46$ & $3-8$ \\
\hline Vit A (IU) & $8-27$ & $4.3-4.4$ & - & $21-25$ & $21-150$ & $03-0.7$ \\
\hline Vit E (IU) & $0.7-1.2$ & $8.3-8.6$ & - & $1.0-2.3$ & $1.4-13$ & $0.8-1.0$ \\
\hline Thiamine (mg) & $0.2-0.3$ & - & $0.2-0.3$ & $0-0.4$ & $0-0.6$ & - \\
\hline Riboflavin (mg) & $1.1-3.5$ & - & $0.2-0.9$ & $0.4-3.4$ & $0.9-1.5$ & $1.5-4.2$ \\
\hline Vit.B12 (mcg) & - & - & - & $5-9$ & - & - \\
\hline
\end{tabular}

From: FAO/INFOODS [18].

The protein content of insects ranges from $7 \%$ to $68 \%$ (Table 1) and in current literature, huge declines in the edible insects' protein content during processing have been identified [20,21]. Non-protein nitrogen (NPN) in insects (chitin, nucleic acids, phospholipids, as well as ammonia in the intestinal tract) could lead to an overestimation of the protein content [22]. For this reason, instead of the conversion factor $(\mathrm{Kp})$ of 6.25 generally used for proteins, a $\mathrm{Kp}$ of 4.76 has been suggested for whole larvae (from Tenebrio molitor, Alphitobius diaperinus and Hermetia illucens) and 5.60 for protein extracts derived from the larvae of the three insects studied [22,23].

Moreover, although some studies on rats have shown that Acheta domesticus cricket could be a good source of protein compared to vegetal sources (e.g., soy) [9,14], proteins from most insect species 
have limited amounts of tryptophan and lysine and their digestibility has been estimated between $77 \%$ and $98 \%[24,25]$.

Table 1 also reports the less saturated fatty acids, more monounsaturated and more polyunsaturated fats compared to meat total fat content present in edible insects, ranging from 1 to $57 \mathrm{~g} / 100 \mathrm{~g}$. Ramos-Elorduy et al. (1997) [25] reported that larvae and some adult insects with a soft body, such as termites, have the highest levels of fat, whilst insects with a hard exoskeleton, such as crickets and grasshoppers, contain smaller amounts. In terms of nutritional quality, the fatty acid composition is generally comparable to that found in poultry and fish, but insects probably contain less saturated fatty acids, more monounsaturated and more polyunsaturated fats compared to meat [1,2].

The fibre content of insects ranges from 1 to $15 \mathrm{~g} / 100 \mathrm{~g}$ (Table 1 ) and is mainly sourced from the exoskeleton of chitin [26]. Although chitin could have positive effects on the immune system [5] and cholesterol levels [27], it has been suggested that chitin removal could improve the digestibility of insect proteins [22].

Micronutrient composition is highly variable and depends on the species of insect. A good source of iron is Mopane worm, with a content that reaches $508 \mathrm{mg} / 100 \mathrm{~g}$ [18]. In many species, the iron content is equal or greater than the iron content in beef [28]. For example, grasshoppers contain $8-20 \mathrm{mg} / 100 \mathrm{~g}$ of iron, whilst the iron content of beef is only $6 \mathrm{mg} / 100 \mathrm{~g}$ [13]. However, since iron absorption in humans is particularly complex and the iron compounds of insects are very different from those found in vertebrates [29], an assessment of the bioavailability, by means of human studies, is needed.

Insect larvae also contain a great amount of zinc $(98 \mathrm{mg} / 100 \mathrm{~g})$ [18]. Recent literature reports that the domestic cricket (Acheta domesticus) contains $29.7 \mathrm{mg} / 100 \mathrm{~g}$ of zinc, whilst the domestic fly (Musca domestica) contains $85.8 \mathrm{mg} / 100 \mathrm{~g}$ [21]; values much higher than zinc levels in meat (an average of $12.5 \mathrm{mg} / 100 \mathrm{~g}$ in beef).

Edible insects are also a significant source of vitamins, especially water-soluble vitamins such as B-vitamins. The Yellow Mealworm (or Flour Mealworm, Tenebrio molitor) is rich in vitamin B2, B6, B9 and B12, although the latter seems to be present only in Tenebrio molitor and Acheta domesticus [1]. Insects are not good sources of vitamin A, whereas commercially reared insects contain high levels of carotenoids [13].

\subsection{Safety}

The use of insects as food has many potential risks [30]. Although several studies have confirmed that levels of oxalate, phytic acid, phenol and tannins in edible insect species were below the toxicity levels for human consumption [31,32], a recent study suggested the possible bioaccumulation of methylmercury (MeHg) in dragonflies [33]. Furthermore, the concentration of exogenous substances (pesticides, lipophilic pollutants, drug residues and other bio-accumulative substances) depends on the metabolic characteristics of the insect and on the rearing methods [9]. Insect production may require pharmacological treatments to counteract possible infections and antibiotics, fungicides and anti-protozoan drugs can be used as possible treatments. The Hazard Analysis Critical Control Points (HACCP) and pre-requisites program (PRP) for insect production, storage, transport and labelling have been recently suggested [34].

The potential of insects to be carriers of pathogens such as protozoans (Entamoeba histolytica, Giardia lamblia, Toxoplasma spp. and Sarcocystis spp.) [35] and trematoda (Dicrocoelium dendriticum) is also a potential risk [36]. Viruses, such as Arboviruses can replicate in insects, in particular in flies and ticks, and can also infect humans [37]. Arboviruses cause diseases such as Dengue, Chikungunya, West Nile Disease, haemorrhagic fever, and Rift Valley fever [37]. However, there is no evidence that these viruses are present in edible species [38]. Moreover, viruses are vulnerable to food processing [38].

Arthropods can induce allergic reactions in humans, due to the presence of tropomyosin (contained also in shellfish and house dust mites), arginine kinase, glyceraldehyde 3-phosphate dehydrogenase, hemocyanine and hexamerin 1B [9,39,40]. Possible cross-reactions to crickets in individuals with a known allergy to crustaceans have been reported [39]. 
The role of arthropods (such as the Musca domestica and Alphitobius diaperinus) as vectors of Salmonella and Campylobacter is widely demonstrated [22]. Casu Marzu, a Sardinian cheese containing living larvae of the fly Piophila casei, is one of the most disputable cheeses in regards to safety issues in Europe, and Article 14 of Regulation (EC) No 178/2002 states that food shall not be placed on the market if deemed unsafe.

The results of national assessments conducted by authorities in Belgium, the Netherlands and France [41-43], have shown a high presence of aerobic and anaerobic bacteria in the Yellow Mealworm (Tenebrio molitor), locusts (Locusta migratoria) and in the larvae of the Giant Mealworm Beetle (Zophobas atratus). The process of roasting did not result in the total elimination of Enterobacteriaceae [44], whereas boiling at $100{ }^{\circ} \mathrm{C}$ for 8 minutes reduced the total aerobic bacterial count and the amount of Enterobacteriaceae to $<10 \mathrm{cfu} / \mathrm{g}$ [42]. It is also possible to reduce the total aerobic bacterial load and the amount of Enterobacteriaceae present in Mealworm larvae (Tenebrio molitor) and house crickets (Acheta domesticus) by drying the insects in an oven for 11 minutes at $90^{\circ} \mathrm{C}$ [45]. The combination of high hydrostatic pressures $(600 \mathrm{MPa})$ and high temperatures $\left(90^{\circ} \mathrm{C}\right)$ also reduced the bacterial count $[1,46]$.

EFSA (2015) examined the potential risk related to the production and consumption of insects as food [38]. The microbial risk of edible species was found to be comparable to that of other animal protein sources [38], however, insects are commonly considered harmful by many consumers and the pursuit of pleasure, the preservation of traditions and the use of local and regional food are all known to affect food choices [47].

\section{Entomophagy Versus Disgust in the World}

In many countries the consumption of insects is part of the culture and tradition and, according to the FAO, insects are a common food source [13]. Insects are currently consumed as part of the daily diet in many developing and non-developing countries, including Africa, Asia, Latin America and Oceania (Figure 1).

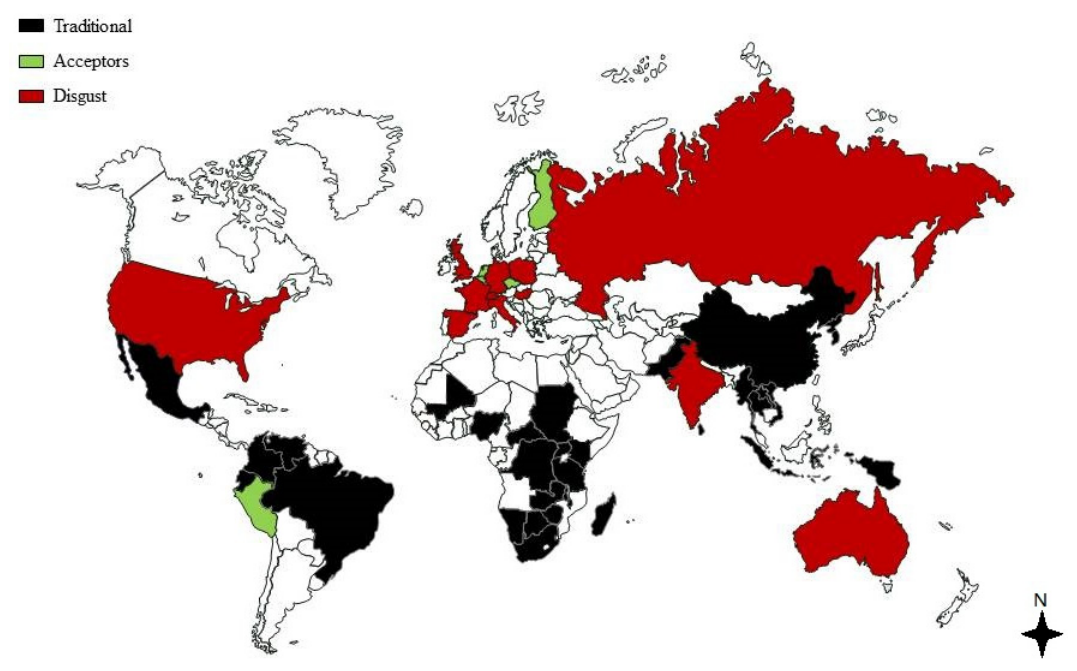

Figure 1. Map of disgust, acceptor and traditional countries [13,48-50].

Insects consumed in developing countries are currently collected in the wild, so their stage of development (larval or adult) and their availability are strictly dependent on seasonality [51]. In Africa, insects can be found throughout the continent and, particularly during the rainy season, the availability of caterpillars may vary even within the same country according to climatic conditions [51]. In Asia, the palm weevil (Rhynchophorus ferrugineus) of the sago palm (Metroxylon sagu) is popular throughout the continent and considered a delicacy in many regions [51]. Edible insects are used also in the Lao People's Democratic Republic, Myanmar, Thailand and Vietnam [22,52]. Furthermore, over 50 species 
of insects are consumed in South Asia, 39 species in Papua New Guinea and the Pacific Islands, and between 150-200 species in Southeast Asia [51].

In the last fifteen years, Thailand has produced an average of 7500 tons of edible insects each year, including crickets, red palm weevils and bamboo caterpillars [53]. In Latin America, amongst the indigenous populations of Mexico and Brazil, there is a deep knowledge of the different species of insects that are traditionally part of their diet (Figure 1) [22]. Examples of traditional Mexican dishes are escamoles (the eggs of Liometopum apiculatum Mayr), larvae of Lepidoptera and Hemiptera [22,54], chapulines (Sphenarium purpurascens) and chicatanas (Atta mexicana) [55]. Furthermore, entomophagy was extremely common amongst Australian Aborigines in the last 200 years, but the consumption of insects has decreased significantly due to the increasing adoption of European diets [22]. In fact, associating insects and diets is often stereotyped as a hallmark of an underdeveloped country or society, however, even in Europe, some types of insects are consumed. Parts or products of insects are eaten as raw snack food in some areas of the Friuli region (North Eastern Italy) such as the ingluvies of adult Lepidoptera (Zygaenidae Zygaena spp. and Ctenuchidae Syntomis spp.) [56]. Casu Marzu a cheese that contains live insect larvae, has a regional identity and is obtained using the milk of goat or sheep in Sardinia. Other examples of these cheeses can be found in other Italian regions including Friuli (Saltarello cheese) and Abruzzo (Marcetto cheese), and many others, such as Gorgonzola delle Grotte and Formaggio di Fossa, also exist. Similar cheeses are found in Corsica (France) and Croatia, as well as the German Milbenkäse or the French Mimolette [56].

A large number of surveys, focusing on European consumers, have shown that the propensity to consume insects as a meat substitute is generally low $[50,57,58]$. Moreover, participants who have previously eaten insects are more likely to eat them again [59,60]. In Holland, typical Dutch dishes such as burgers, nuggets and pittige punten (a spicy triangular product, similar in appearance to a hash brown or potato croquette), which are usually made from meat, were produced using vegetables and the ground larvae of the beetle Alphitobius diaperinus [47]. Consumers stated that the larvae were not visible, the taste of insects was not particularly identifiable and that the products were cooked similarly to conventional vegetarian foods. In this study, repeated consumption of insect-based products was relatively low ( $58 \%$ testing them only once; $18 \%$ more than once but not regularly; $24 \%$ semi-regular consumption; around 3\% once every two weeks, weekly or twice a week) [47]. Initial reasons of consumption were dictated by a general interest or curiosity, by the feeling that insects are more environmentally friendly or sustainable than conventional meat-based products and by the belief that they are an alternative source of protein for a healthy diet. The participants' general dietary guidelines had some influence with the preference for organic food being commonly reported amongst participants (mentioned by $42 \%$ of the group) [47].

Pambo et al. (2018) examined how consumers assess the appropriateness of sensory attributes of edible insects. The type of information that consumers received about the production process influenced the sensory assessment after tasting [61]. Another factor that could improve the acceptance of insects is the use of evocative names for insect recipes, which would attract attention and generate a good consumer expectation [62]. In addition, Castro and Chambers [63] suggested that insect-based product should not contain visible insect pieces, which trigger negative associations. In particular, the addition of cricket flour to traditionally consumed foods, could be an attractive option to introduce insects into diets without altering eating habits [22]. On the other hand, informing consumers about the reduced environmental impact deriving from the consumption of insects, can represent another strategy to increase insect consumption $[20,60,64]$.

Biological, psychological and socio-cultural factors are known to influence food choices. Culture, in particular, influences what is considered edible, with many people in Western countries rejecting the idea of entomophagy mainly for cultural reasons. In a multi cross-cultural international survey including 630 individuals per country and representing 13 different countries (USA, Mexico, Peru, Brazil, UK, Spain, Russia, India, China, Thailand, Japan, South Africa, and Australia), authors identified "disgust" and "acceptor" countries (Figure 1) [48,63]. Compared to the UK [49], the likelihood of eating 
insect-based protein sources was more than twice in the Netherlands and Finland and 1.5 times in Spain. Willingness to try insect-products was higher in Mexico (71\%), Peru (58\%), Thailand (56\%), Brazil (45\%) and China (44\%), but surprisingly lower in Japan (21\%), where insects are part of the traditional diet and wasps are considered a highly sought-after food. Other countries had intermediate values $(32 \%-36 \%)$ [48]. Although there are still several species that are eaten and considered a delicacy in Japan [65], a low willingness to try new-foods was found, probably due to the Japanese traditional diet [48]. The Japanese and the Mediterranean diet are considered healthy eating models [66-68], and this probably increases the attachment to eating traditional. The Mediterranean diet is included in the UNESCO Representative List of the Intangible Culture Heritage of Humanity [2] as it is a cultural product in an anthropological sense, and a lifestyle based on the conviviality of meals. For instance, food may enhance family unity when members consume it together [69]. Whilst the traditional food "Italian zampone" has been avoided in the Food Disgust Picture Scale (FDPS) [70], food "neophobia" (the fear of new or unfamiliar foods) [71] is associated with distaste [72] and could be higher in populations with strong traditional eating habits.

\section{The Role of Food Neophobia on the Intention to Consume Insects in Italy}

Sixteen reviewed studies (from 19 publications), involving Italian individuals (Table 2), identified: food neophobia scale (FNS), willingness to try (WTT) or intention (ITE) or willingness to eat (WTE) or willingness to consume (WTC), willingness to pay (WTP), willingness to buy (WTB) and entomophagy attitude questionnaire (EAQ). Several definitions have been proposed to describe the intention to consume insect as food and in the light of these different definitions, it should not surprising that consumer intention for insects as food has been described in diverse way (WTT, WTE, WTC and ITE).

Table 2. Studies involving Italian individuals.

\begin{tabular}{|c|c|c|c|}
\hline Sample (n) & Design & Major Results & Ref. \\
\hline $\begin{array}{l}\text { North Italy (Bolzano*): } \\
\text { International university } \\
\text { students (n.125), } \\
\text { (trilingual: English, } \\
\text { German and Italian) } \\
\text { *[border with Austria } \\
\text { region of Italian Alps] }\end{array}$ & $\begin{array}{l}\text { FNS } \\
\text { WTC Chontacuros } \\
\text { (Rhynchophorus palmarum } \\
\text { L.): an insect species } \\
\text { considered a delicacy } \\
\text { amongst indigenous } \\
\text { people and settlers of the } \\
\text { Ecuadorian Amazon } \\
\text { rainforest. }\end{array}$ & $\begin{array}{l}\text { FNS negatively influences WTC. } \\
\text { Persuasion strategies positively influence } \\
\text { WTC. }\end{array}$ & [12] \\
\hline $\begin{array}{l}\text { North Italy (Milan) } \\
\text { university students, } \\
\text { employees and } \\
\text { consumers from outside } \\
\text { the university (n.341: } 223 \\
\text { females and } 118 \\
\text { males-18-80 years) }\end{array}$ & $\begin{array}{l}\text { Questionnaire: } \\
\text { willingness to incorporate } \\
\text { insects into diets } \\
\text { Subjects divided in } 3 \\
\text { groups: } \\
\text { "low neophobia" (FNS } \\
\text { scores } \leq 23, \mathrm{n}=86 \text { ), } \\
\text { "medium neophobia" } \\
\text { (FNS scores } \geq 24 \text { and } \leq \\
41, \mathrm{n}=166 \text { ) } \\
\text { "high neophobia" (FNS } \\
\text { scores } \geq 42, \mathrm{n}=89 \text { ) }\end{array}$ & $\begin{array}{l}\text { People with Low level of food neophobia were } \\
\text { significantly more willing to accept insects } \\
\text { as feed, as food and served in an ethnic } \\
\text { restaurant than people with a medium level } \\
\text { of food neophobia who, in turn, showed a } \\
\text { significantly higher readiness than } \\
\text { neophobic consumers. } \\
\text { Younger people more readily accepted } \\
\text { insects. } \\
\text { University students and staff (e.g., High } \\
\text { level of education) more readily accepted } \\
\text { insects. } \\
\text { Environmental and nutritional benefits } \\
\text { marginally affected the acceptability of } \\
\text { insect-based foods. }\end{array}$ & [73] \\
\hline
\end{tabular}


Table 2. Cont.

\begin{tabular}{|c|c|c|c|}
\hline Sample (n) & Design & Major Results & Ref. \\
\hline $\begin{array}{l}\text { North Italy (Milan) and } \\
\text { South Italy (Bari) } \\
\text { university students } \\
\text { (n.35561, 69\% female, } \\
\text { 18-29 years }\end{array}$ & $\begin{array}{l}\text { Online questionnaires } \\
\text { concerning the WTT } \\
\text { different food containing } \\
\text { insect or earthworm } \\
\text { ingredients }\end{array}$ & $\begin{array}{l}38 \% \text { more likely to consider insect- food } \\
\text { part of Italian diet, } 32 \% \text { rejected. } \\
\text { Insects/earthworms more accepted in salty } \\
\text { snacks. } \\
\text { Gender influenced WTT. }\end{array}$ & [74] \\
\hline $\begin{array}{l}\text { North Italy (Padua) } \\
\text { university students with } \\
\text { part-time occupation } \\
\text { (72\%) plus employees in } \\
\text { several jobs (n.32-20-35 } \\
\text { years) }\end{array}$ & $\begin{array}{l}\text { WTE } \\
\text { Insect-based food: } \\
\text { cheddar cheese larvets, } \\
\text { lollipops, chocolate } \\
\text { covered scorpions, salt } \\
\text { infused with chili and } \\
\text { agave worms, dried } \\
\text { crickets, baked } \\
\text { grasshoppers, toasted } \\
\text { scorpions }\end{array}$ & $\begin{array}{l}\text { WTE is dependent on the form in which the } \\
\text { products are presented. } \\
\text { Crustaceans were frequently mentioned as } \\
\text { a comparison in terms of distaste. }\end{array}$ & [75] \\
\hline $\begin{array}{l}\text { North Italy (Parma) } \\
\text { (n.46 individuals } \\
\text { recruited at a "bug } \\
\text { banquet") }\end{array}$ & $\begin{array}{l}\text { The nutritional and the } \\
\text { environmental benefits } \\
\text { of entomophagy were } \\
\text { explained Tasting } \\
\text { insects:-House cricket } \\
\text { (Acheta domesticus) } \\
\text {-Wax moth larvae } \\
\text { (Galleria mellonella) } \\
\text {-Grasshoppers } \\
\text { (Calliptamus italicus) }\end{array}$ & $\begin{array}{l}\text { WTT is determined by curiosity and disgust. } \\
63 \% \text { of the sample who tasted the insects } \\
\text { preferred wax moth larvae, followed by } \\
\text { locusts (19\%) and crickets (12\%); } 6 \% \\
\text { indicated that none of the three species } \\
\text { above were preferred. }\end{array}$ & [76] \\
\hline $\begin{array}{l}\text { North Italy (Parma) } \\
\text { university students } \\
\text { (n.109, 53\% females, } \\
\text { 18-25 years) }\end{array}$ & $\begin{array}{l}\text { WTT } \\
\text { "Bug tasting session": } \\
\text { Cookie product made by } \\
\text { replacing } 10 \% \text { of the } \\
\text { traditional flour with } \\
\text { "cricket flour" (Acheta } \\
\text { domesticus). }\end{array}$ & $\begin{array}{l}47 \% \text { believed that entomophagy might } \\
\text { become a culinary trend in Italy, whilst the } \\
\text { other half states that it would not be } \\
\text { "successful", "appropriate" or "exciting. } \\
67.5 \% \text { indicated they would taste edible } \\
\text { insects if they had the opportunity. } \\
\text { "Bug-tasting session": } 94 \% \text { of the students } \\
\text { agreed to eat the insect-based food. }\end{array}$ & [77] \\
\hline $\begin{array}{l}\text { North Italy (Parma) } \\
\text { university students } \\
\text { (n.231, 62\% female, mean } \\
\text { age } 23.6 \pm 3.8 \text { years. }\end{array}$ & $\begin{array}{l}\text { ITE } \\
\text { Tasting: chocolate chip } \\
\text { cookie containing } 10 \% \text { of } \\
\text { cricket flour (Acheta } \\
\text { domesticus) }\end{array}$ & $\begin{array}{l}\text { Weak ITE products containing insect flour. } \\
\text { Only } 110 \text { individuals ITE and only } 53(22.9 \% \\
\text { of the total) students tasted the novel food. }\end{array}$ & {$[78,79]$} \\
\hline $\begin{array}{l}\text { North Italy (Parma): } \\
\text { university students and } \\
\text { staff (n. } 88,45 \\
\text { females, } 18-40 \text { years from: } \\
20 \% \text { North East, } 36 \% \\
\text { North West, } 14 \% \text { Central } \\
\text { and } 30 \% \text { Southern Italy). }\end{array}$ & $\begin{array}{l}\text { FNS, WTT. } \\
\text { Tasting two sweet jellies: } \\
\text { one with a visible cricket } \\
\text { (unprocessed) and one } \\
\text { with a processed cricket. }\end{array}$ & $\begin{array}{l}\text { WTT is affected by the FNS. } \\
\text { Males were more WTT new foods. } \\
\text { WTT-unprocessed }<\text { WTT-processed } \\
\text { insect-based product. } \\
75 \% \text { tasted both products } \\
19 \% \text { tasted only the insect-based jelly } \\
6 \% \text { did not try either product }\end{array}$ & {$[11,80,81]$} \\
\hline $\begin{array}{l}\text { Central Italy (Pisa) } \\
\text { university students } \\
\text { (n.165) }\end{array}$ & $\begin{array}{l}\text { Informative seminar } \\
\text { entitled "Insects as Food } \\
\text { and Feed: Future } \\
\text { Prospects" } \\
\text { n. } 66 \text { [40\%] took part of a } \\
\text { tasting session: two } \\
\text { bread samples identical, } \\
\text { except one was claimed } \\
\text { to be supplemented with } \\
\text { insect powder, e.g., } \\
\text { "insect-labelled" bread, } \\
\text { although it did not } \\
\text { contain any insect } \\
\text { ingredients. }\end{array}$ & $\begin{array}{l}\text { No gender impact. } \\
\text { WTT is positively affected by behavioural } \\
\text { intention. The belief of positive effects on } \\
\text { health has a stronger influence on } \\
\text { behavioural intentions when compared to } \\
\text { beliefs about environmental protection and } \\
\text { familiar taste. } \\
\text { After the seminar, disgust factor and the } \\
\text { fear of negative texture properties was } \\
\text { reduced. }\end{array}$ & [82] \\
\hline
\end{tabular}


Table 2. Cont.

\begin{tabular}{|c|c|c|c|}
\hline Sample (n) & Design & Major Results & Ref. \\
\hline $\begin{array}{l}\text { Central Italy (Viterbo) } \\
\text { (n.201, female: } 55 \% \text {, } \\
\text { mean age } 43 \text { years) } \\
\text { Education: } \\
\text { 19\%lower, } 49 \% \text { secondary, } \\
32 \% \text { university }\end{array}$ & $\begin{array}{l}\text { Insect pictures were } \\
\text { showed: } \\
\text { Insect-based preparation } \\
\text { comparable to sushi } \\
\text { Street food stand with } \\
\text { fried insects } \\
\text { Skewers with pupae } \\
\text { Plate with larvae and } \\
\text { pupae with some } \\
\text { vegetables } \\
\text { Meat burger with some } \\
\text { larvae on the top }\end{array}$ & $\begin{array}{l}31 \% \text { WTT insects as food } \\
5 \% \text { had already tried insects } \\
\text { The fear of insects and the idea that the } \\
\text { taste might be disgusting were the main } \\
\text { barriers to the WTT } \\
\text { Familiarity with foreign food, higher } \\
\text { education and gender (male) positively } \\
\text { influenced consumer attitude to } \\
\text { entomophagy. }\end{array}$ & [83] \\
\hline $\begin{array}{l}\text { South Italy (Naples) } \\
\text { university students } \\
\text { (n.118: } 58 \text { females and } 60 \\
\text { males) }\end{array}$ & $\begin{array}{l}\text { Computer questionnaire } \\
\text { "Insects vs. flowers" } \\
\text { FNS } \\
\text { Disgust sensitivity scale }\end{array}$ & $\begin{array}{l}\text { FNS significantly correlates with intention } \\
\text { but not with disgust. } \\
\text { Intention correlated significantly with } \\
\text { disgust. }\end{array}$ & [84] \\
\hline $\begin{array}{l}\text { South Italy (Naples) } \\
\text { (n.200 university } \\
\text { students, } 40 \% \text { female, } \\
18-20 \text { years) }\end{array}$ & $\begin{array}{l}\text { General information on } \\
\text { benefits on health and } \\
\text { environment were given. } \\
\text { WTP of } 3 \text { categories of } \\
\text { foods (pasta, cookies and } \\
\text { chocolate bars) with } \\
\text { insects (and their } \\
\text { conventional } \\
\text { counterparts were } \\
\text { evaluated). }\end{array}$ & $\begin{array}{l}\text { Without information: } \\
\text { - insect-based products lower WTP in the } \\
\text { case of cookies and chocolate } \\
\text { - same WTP for the two versions of pasta } \\
\text { With information on benefits: consumers' } \\
\text { WTP increase for all the products. } \\
\text { Food Neophobia negatively affected the } \\
\text { WTP for insect-based products }\end{array}$ & [85] \\
\hline $\begin{array}{l}\text { South Italy (Naples) } \\
\text { students or just } \\
\text { graduates (n.45) }\end{array}$ & $\begin{array}{l}\text { Drivers of acceptance to } \\
\text { insects. }\end{array}$ & $\begin{array}{l}\text { Curiosity drives acceptance. } \\
\text { Disgust and food neophobia were related to } \\
\text { low acceptance. }\end{array}$ & [86] \\
\hline $\begin{array}{l}\text { Italians ( } \mathrm{n} .135 \\
\text { individuals, } 46 \% \text { female, } \\
\text { 18-35 years) }\end{array}$ & $\begin{array}{l}\text { Insect pictures were } \\
\text { showed: } \\
\text { Flour/whole insects } \\
\text { Opaque/transparent } \\
\text { packaging } \\
\text { Cacao flavor } \\
\text { High protein content } \\
\text { (30\% of protein content) } \\
\text { Environmental } \\
\text { certification }\end{array}$ & $\begin{array}{l}\text { Flour-based products WTB > whole insect } \\
\text { products. } \\
\text { No different WTB: } \\
\text { - Transparent vs. opaque packaging - cacao } \\
\text { flavor (Food Neophobia increased WTB for } \\
\text { cacao flavor presence) } \\
\text { - high protein claim } \\
\text { - environmental certification }\end{array}$ & [87] \\
\hline $\begin{array}{l}\text { Italians (n.128) } \\
\text { Danish (n.136) }\end{array}$ & $\begin{array}{l}\text { Communication of } \\
\text { societal benefits and } \\
\text { individual benefits } \\
\text { ITE }\end{array}$ & $\begin{array}{l}\text { Communication increased ITE. } \\
\text { Danish participants had higher ITE than } \\
\text { Italians. }\end{array}$ & [60] \\
\hline $\begin{array}{l}\text { Italian (n.543) } \\
\text { Danish (n.975) }\end{array}$ & $\begin{array}{l}\text { EAQ (EAQ-I; EAQ-D; } \\
\text { EAQ-F) } \\
\text { Disgust Scale } \\
\text { FNS } \\
\text { WTE }\end{array}$ & $\begin{array}{l}\text { Negative relation EAQ-F vs. WTE, found } \\
\text { only in the Danish population. } \\
\text { Danish: EAQ-I main predictor. } \\
\text { Regression coefficient EAQ-D vs. WTE is } \\
\text { much smaller than that of EAQ-I. } \\
\text { Italians: no such great difference between } \\
\text { predictive power of EAQ-D and EAQ-I on } \\
\text { WTE. }\end{array}$ & [88] \\
\hline
\end{tabular}

$\mathrm{EAQ}=$ entomophagy attitude questionnaire; EAQ-I=interest subscale of EAQ; EAQ-D=disgust subscale of EAQ; EAQ-F=feeding animals subscale of EAQ; FNS=food neophobia scale; ITE: intention to eat; WTE: willingness to eat; WTC: willingness to consume; WTT=willingness to try; WTP=willingness to pay; WTB=willingness to buy.

FNS was described by one third of the studies (Table 2). One study involved 88 subjects aged between 18 and 40 years, and included students and staff (43 males and 45 females) [11,80,81]. The participants came from different geographical areas of Italy (20\% North East, 36\% North West, $14 \%$ 
Central Italy and 30\% Southern Italy) and the questionnaire included the FNS and WTT. At the end of the questionnaire, two insect-based products (two sweet jellies with visible or processed cricket) were tasted. The results confirmed that the intention to taste is the most decisive factor for predicting the behaviour of consuming a new insect-based product. This intention is significantly determined by food neophobia and males were more WTT new foods $[11,80,81]$. In this study $75 \%$ of participants tasted the products and, concerning the tasting session of the reviewed studies (Table 2), percentages between $23 \%$ and $94 \%$ of the individuals (in the majority of the studies University students) were reported.

An online survey aimed at 3556 Italian university students aged 18-29 years old, found that $38 \%$ of the respondents were prone to consider that this food could be part of Italian diet. Reasonably, insect-food could be offered in a snack (where they would not be immediately recognizable) as a complementary source of proteins, considering that demand for proteins cannot be totally satisfied by the traditional livestock industry [74].

A study that evaluated WTE different insect-based food (cheddar cheese larvets, lollipops, chocolate covered scorpions, salt infused with chili and agave worm, dried crickets, baked grasshoppers and toasted scorpions) found that WTE was dependent on the form in which the products were presented [75].

Another analysis regarding Italy [76] showed that not only curiosity but also a focus on environmental benefits might be motivating factors to promote entomophagy amongst Italian consumers. The belief that insects have positive effects on the environment and relatively healthy and nutritious, increases the level of acceptance. Curiosity is also reported as a strong motivating factor [76] (Table 2) in fact, it was found to be one of the most significant drivers for acceptance in Southern Italy, whereas disgust and food neophobia were related to low acceptance [86]. One study, conducted in 2015 on a sample of 45 consumers ( 24 females and 21 males, aged between 24 and 39 years, students or just graduates), revealed the major barriers to the acceptance of insects as food are low familiarity with insect-based ingredients, neophobia, and/or visibility of insects in the product [86]. A soft laddering interview (free conversation) was performed to discover the personal values linked to attributes of the product which were perceived as benefits by the consumer. Interviews were conducted in the area of Naples. Kelly's repertory grids (1955) were used and each consumer was shown three different imaginary products, similar to those already available in international online stores. From this study, it seems that curiosity is one of the most significant drivers for acceptance [86]. In another study conducted in South Italy, FNS significantly correlated with intention but not with disgust and the latter correlated significantly with intention [84].

The fear of insects and the idea that the taste might be disgusting, were the main barriers to the WTT entomophagy in Central Italy (Viterbo) [83] and gender also influenced consumer attitude (Table 2). On the other hand, no gender impact was observed in a recent study conducted at the University of Pisa (Italy) amongst students attending a seminar titled "Insects as Food and Feed: Future Prospects" [82]. Disgust factor decreased after the seminar, but volunteers indicated that they were less likely to use the "insect-labelled" bread, which was claimed to be supplemented with insect powder, in the future, despite the higher overall liking. The perception of positive effects on health had a stronger influence on behavioural intentions when compared to beliefs about environmental protection and familiar taste.

Despite bad taste being an important barrier to acceptance, disgust factor and the fear of negative texture properties were strongly reduced after the seminar generating a lower rejection.

WTT was positively affected by behavioural intention. Students from South Italy [85] considered insect-based products either equivalent (the same WTP for the two versions of pasta) or slightly inferior (lower WTP in the case of cookies and chocolate) without information, whilst with information on benefits, consumers' WTP increased for all the products.

Another study based in Italy, investigated the role that product attributes can have in driving the perceptions of consumers of insect-based products. To a sample of 135 individuals were shown a series of products cards describing the products and they were asked to express their opinion. All the 
respondents reacted more positively to products made out of insect flour compared to the ones made with whole insects. Moreover, there were no incisive differences between opaque and transparent packaging. Neither the effect of cacao flavor nor the high-protein claim were statistically significant. Finally, the effect of the environmental certification appears to be not important in the food decision [87]. In a study conducted in an international university (trilingual: English, German and Italian), despite using persuasion strategies (including grounding insects into flour, disguising insects with cocoa, other peers' reassuring statements on food safety, pleasant taste and availability) which positively influenced WTC [12], FNS negatively influenced both WTC and persuasion strategies [12].

In another study conducted in North Italy on 109 university students [77], more than two thirds of the subjects indicated they would taste edible insects if they had the opportunity and about half of the sample believed that entomophagy might become a culinary trend in Italy. However, high levels of education were shown to positively influence consumer attitude towards entomophagy [73,83]; therefore, opinions of university students could not be taken as being representative of the general population.

Additionally, from a study conducted in North Italy and involving university students, employees and consumers from outside the university ( 223 females and 118 males-aged between 18-80 years), it was observed that younger people more readily accepted insects [73]. The authors, by grouping individuals according to FNS "low neophobia" (FNS scores $\leq 23$ ), "medium neophobia" (FNS scores $\geq 24$ and $\leq 41$ ) and "high neophobia" (FNS scores $\geq 42$ ), found a relationship between FNS and willingness to incorporate insects into diets and that environmental and nutritional benefits marginally affected the visual acceptability of insect-based foods. [73]. Although communication of both societal and individual benefits increased ITE, it has been reported that Danish individuals had higher ITE than Italians [60]. By using the EAQ (EAQ-I; EAQ-D; EAQ-F) differences were found between the Danes and Italians [88]. The EAQ includes three conceptual scores: disgust (EAQ-D), interest (EAQ-I) (including curiosity) and feeding animals (EAQ-F). The latter comprises the following sentence: "Using insects as feed is a good way of producing meat and I think it is fine to give insect-based feed to fish that are farmed for human consumption". In the Danish volunteers, EAQ-I was the main predictor and regression coefficient EAQ-D vs. WTE insects, was much smaller than that of EAQ-I. A negative relationship of EAQ-F vs. intention toward direct entomophagy was found only in the Danish population. Amongst Italians no such difference between predictive power of EAQ-D and EAQ-I on WTE was found [88].

\section{Discussion and Conclusions}

Entomophagy is common in some Asian, American and African countries, whilst it is generally rejected by Western populations [12] and is often considered a "barbarian" tradition by Western culture [11]. Western food taboos, such as entomophagy, could be encouraged by cultural aspects in which insects are considered noxious products [89]. Western society generally regards insects as a food of emergency, not only associated with low prestige and indigent countries [76], but also with filth, danger or the psychological idea of possible contamination [72]. The Western reluctance towards entomophagy should not be classified as a mere form of disgust but as a form of acquired distaste derived from a lack of habits, and exposure not only to the flavour of insects but also their visual, tactile, olfactory and auditory properties and their sensory representation on dishes. Distaste has been defined as 'a form of motivated food rejection triggered by the ingestion of unpleasant tasting substances, prototypically those that are bitter' [72], whose function is to avoid the ingestion of toxic compounds. Although it has been reported that curiosity is a strong motivational factor for trying insects [72], Italians tend to follow a diet based on the protective Mediterranean model [2].

Leon Rappoport analysing the social and psychological components of food claims: 'Consciously or not, when we eat we swallow not only a certain alimentary product, but also the concept, the culture, and the land to which it is associated with' [90]. It has been suggested that rational theoretical assumptions encouraging "healthier" alimentary choices via prescriptive and legislative measures (e.g., sugar tax) are not the optimal strategies in the Italian context [2]. In Italy it has been reported that the 
belief of positive effects on health has a stronger influence on behavioural intentions than beliefs about environmental protection [82]. The potential success of a strategy in a country might be not suitable for another one. For example, the UK sugar tax may improve public health [91] but it seems not to be a useful strategy in Italy [2]. Briggs (2016) stated: 'Agriculture is responsible for up to $30 \%$ of the world's greenhouse-gas emissions, yet it is often overlooked in climate discussions and was barely mentioned at December's United Nations climate talks in Paris. Taxing food that is responsible for high greenhouse-gas emissions when it is produced and transported could benefit the health of both people and the planet. Sugar is a good start, but we can aim higher' [91]. These sentences should make people engaged in health promotion campaigns of agri-food products and could alarm Italians, particularly tied to Mediterranean culinary traditions. It has been suggested that in Italy traditional values, such as the Mediterranean diet, might reduce the diffusion of genetically modified organisms-based foods [92].

Despite organic aquaculture might be a new and important strategy for diversification and labelling/certification are not taken into consideration, the added value of the production method might not be perceived by the final consumers that show a higher WTP for the sea bass country of origin than for the breeding method used [93]. Moreover, local origin geographic origin of honey accounted for $72.9 \%$ of the log-likelihood, followed by price and organic production [94].

Geographic origin is important also when choosing bovine meat and celebrating "Protected Geographical Indication" (PGI) Italy ranked first for an anniversary and a meal with friends [95].

In a study that explored consumers' attitude towards cultured meat in Italy, people from northern Italy showed a significantly more positive perception towards attributes such as safety and sustainability than respondents from central and southern Italy [96]. In Italy the Sardinian sheep milk cheese "Casu $M a r z u^{\prime \prime}$ is well known and eaten, as well as other regional cheeses and some parts of Lepidoptera in Northern Italy are eaten [56]. In the present review, studies have been conducted in North [12,73,75-79], Central $[82,83]$ and South Italy [84-86] and two studies involved volunteers from different Italian regions $[11,74,80,81]$. However, more research needs to be carried out to evaluate the effect of cultural variations exist among Italians of North, Centre and South on food neophobia and insects' acceptance.

In conclusion, in order to introduce insects into the Italian diet, psychological motivation has to be enhanced.

Author Contributions: I.P. conceived the idea, P.A., A.K. and L.M. reviewed the literature, E.T., M.P. and P.A. drafted the manuscript, I.P. and E.T. critically revised and approved the final version before submission. All authors have read and agreed to the published version of the manuscript.

Funding: This research received no external funding.

Acknowledgments: The authors would like to thank Kathleen Dunbar for language revision of the manuscript.

Conflicts of Interest: The authors declare no conflict of interest.

\section{References}

1. Rumpold, B.A.; Schlüter, O.K. Nutritional composition and safety aspects of edible insects. Mol. Nutr. Food Res. 2013, 57, 802-823. [CrossRef]

2. Poli, A.; Agostoni, C.; Graffigna, G.; Bosio, C.; Donini, L.M.; Marangoni, F. The complex relationship between diet, quality of life and life expectancy: A narrative review of potential determinants based on data from Italy. Eat. Weight Disord. Stud. Anorex. Bulim. Obes. 2018, 24, 411-419. [CrossRef]

3. Premalatha, M.; Abbasi, T.; Abbasi, T.; Abbasi, S. Energy-efficient food production to reduce global warming and ecodegradation: The use of edible insects. Renew. Sustain. Energy Rev. 2011, 15, 4357-4360. [CrossRef]

4. Oonincx, D.G.A.B.; Van Itterbeeck, J.; Heetkamp, M.J.W.; Brand, H.V.D.; Van Loon, J.J.A.; Van Huis, A. An Exploration on Greenhouse Gas and Ammonia Production by Insect Species Suitable for Animal or Human Consumption. PLoS ONE 2010, 5, e14445. [CrossRef]

5. Van Huis, A. Potential of Insects as Food and Feed in Assuring Food Security. Annu. Rev. Èntomol. 2013, 58, 563-583. [CrossRef] 
6. Megido, R.C.; Sablon, L.; Geuens, M.; Brostaux, Y.; Alabi, T.; Blecker, C.; Drugmand, D.; Haubruge, E.; Francis, F. Edible Insects Acceptance by Belgian Consumers: Promising Attitude for Entomophagy Development. J. Sens. Stud. 2013, 29, 14-20. [CrossRef]

7. Henchion, M.; Hayes, M.; Mullen, A.M.; Fenelon, M.A.; Tiwari, B.K. Future Protein Supply and Demand: Strategies and Factors Influencing a Sustainable Equilibrium. Foods 2017, 6, 53. [CrossRef] [PubMed]

8. Lähteenmäki-Uutela, A.; Grmelová, N.; Hénault-Ethier, L.; Deschamps, M.-H.; Vandenberg, G.W.; Zhao, A.; Zhang, Y.; Yang, B.; Nemane, V. Insects as Food and Feed: Laws of the European Union, United States, Canada, Mexico, Australia, and China. Eur. Food Feed Law Rev. 2017, 12, 22-36.

9. Belluco, S.; LoSasso, C.; Maggioletti, M.; Alonzi, C.C.; Paoletti, M.G.; Ricci, A. Edible Insects in a Food Safety and Nutritional Perspective: A Critical Review. Compr. Rev. Food Sci. Food Saf. 2013, 12, 296-313. [CrossRef]

10. Italian Ministry of Health. Informativa in merito all'uso di insetti in campo alimentare con specifico riferimento all'applicabilità del Regolamento (UE) 2015/2283 sui novel food. Ministry of Health, Rome, Italy; 2018. Available online: http://www.trovanorme.salute.gov.it/norme/renderNormsanPdf?anno=2018\& codLeg=62647\&parte $=1 \% 20 \&$ serie $=$ null (accessed on 31 April 2020).

11. Sogari, G.; Menozzi, D.; Mora, C. The food neophobia scale and young adults' intention to eat insect products. Int. J. Consum. Stud. 2018, 43, 68-76. [CrossRef]

12. Sidali, K.L.; Pizzo, S.; Garrido-Pérez, E.I.; Schamel, G. Between food delicacies and food taboos: A structural equation model to assess Western students' acceptance of Amazonian insect food. Food Res. Int. 2019, 115, 83-89. [CrossRef] [PubMed]

13. van Huis, A.; van Itterbeeck, J.; Klunder, H.; Mertens, E.; Halloran, A.; Muir, G.; Vantomme, P. Edible Insects: Future Prospects for Food and Feed Security; FAO FORESTRY PAPER: Rome, Italy, 2013; Volume 171.

14. Jongema, Y. Worldwide List of Recorded Edible Insects; Wageningen University \& Research on Social Media: Wageningen, The Netherlands, 2017; Available online: https:/www.wur.nl/upload_mm/8/a/6/0fdfc7003929-4a74-8b69-f02fd35a1696_Worldwide\%20list\%20of\%20edible\%20insects\%202017.pdf (accessed on 25 October 2019).

15. Finke, M.D. Complete nutrient composition of commercially raised invertebrates used as food for insectivores. Zoo Boil. 2002, 21, 269-285. [CrossRef]

16. Payne, C.; Scarborough, P.; Rayner, M.; Nonaka, K. A systematic review of nutrient composition data available for twelve commercially available edible insects, and comparison with reference values. Trends Food Sci. Technol. 2016, 47, 69-77. [CrossRef]

17. Ekpo, K. Effect of processing on the protein quality of four popular insects consumed in Southern Nigeria. Arch. Appl. Sci. Res. 2011, 3, 307-326.

18. Charrondière, U.R.; Stadlmayr, B.; Rittenschober, D.; Mouillé, B.; Nilsson, E.; Medhammar, E.; Olango, T.; Eisenwagen, S.; Persijn, D.; Ebanks, K.; et al. FAO/INFOODS food composition database for biodiversity. Food Chem. 2013, 140, 408-412. [CrossRef] [PubMed]

19. Charrondiere, R.U.; Stadlmayr, B.; Rittenschober, D.; Grande, F.; Nowak, V. FAO/INFOODS Food Composition Database for Biodiversity, Version 4.0-BioFoodComp4.0. In Food and Agriculture Organization of the United Nations; FAO: Rome, Italy, 2017.

20. Kim, T.-K.; Yong, H.I.; Kim, Y.-B.; Kim, H.-W.; Choi, Y.-S. Edible Insects as a Protein Source: A Review of Public Perception, Processing Technology, and Research Trends. Food Sci. Anim. Resour. 2019, 39, 521-540. [CrossRef]

21. Williams, J.P.; Williams, J.R.; Kirabo, A.; Chester, D.; Peterson, M. Chapter 3-Nutrient content and health benefits of insects. In Insects as Sustainable Food Ingredients: Production, Processing and Food Applications; Dossey, A.T., Morales-Ramos, J.A., Rojas, M.G., Eds.; Academic Press: San Diego, CA, USA, 2016; pp. 61-84.

22. Bessa, L.W.; Pieterse, E.; Sigge, G.; Hoffman, L.C. Insects as human food; from farm to fork. J. Sci. Food Agric. 2018. [CrossRef]

23. Janssen, R.H.; Vincken, J.-P.; Broek, L.A.V.D.; Fogliano, V.; Lakemond, C. Nitrogen-to-Protein Conversion Factors for Three Edible Insects: Tenebrio molitor, Alphitobius diaperinus, and Hermetia illucens. J. Agric. Food Chem. 2017, 65, 2275-2278. [CrossRef]

24. Chen, X.M.; Feng, Y.; Zhang, H.; Chen, Z. Review of the nutritive value of edible insects. In Forest Insects as Food: Humans Bite Back, Proceedings of a Workshop on Asia-Pacific Resources and their Potential for Development, Chiang Mai, Thailand, 19-21 February 2008; Durst, P.B., Johnson, D.V., Leslie, R.N., Shono, K., Eds.; Food and Agriculture Organization of the United Nations (FAO): Rome, Italy, 2010; ISBN 9789251064887. 
25. Ramos-Elorduy, J.; Moreno, J.M.P.; Prado, E.E.; Perez, M.A.; Otero, J.L.; De Guevara, O.L. Nutritional Value of Edible Insects from the State of Oaxaca, Mexico. J. Food Compos. Anal. 1997, 10, 142-157. [CrossRef]

26. Muzzarelli, R. Chitosans depolymerized with the aid of papain and stabilized as glycosylamines. Carbohydr. Polym. 2002, 50, 69-78. [CrossRef]

27. Zielińska, E.; Karaś, M.; Jakubczyk, A.; Zieliński, D.; Baraniak, B. Edible Insects as Source of Proteins. In Bioactive Molecules in Food; Mérillon, J.-M., Ramawat, K.G., Eds.; Springer International Publishing: Cham, Switzerland, 2018; pp. 1-53. [CrossRef]

28. Mwangi, M.N.; Oonincx, D.G.A.B.; Stouten, T.; Veenenbos, M.; Melse-Boonstra, A.; Dicke, M.; Van Loon, J.J.A. Insects as sources of iron and zinc in human nutrition. Nutr. Res. Rev. 2018, 31, 248-255. [CrossRef] [PubMed]

29. Whiten, S.R.; Eggleston, H.; Adelman, Z.N. Ironing out the Details: Exploring the Role of Iron and Heme in Blood-Sucking Arthropods. Front. Physiol. 2018, 8, 1134. [CrossRef] [PubMed]

30. Schlüter, O.; Rumpold, B.; Holzhauser, T.; Roth, A.; Vogel, R.F.; Quasigroch, W.; Vogel, S.; Heinz, V.; Jäger, H.; Bandick, N.; et al. Safety aspects of the production of foods and food ingredients from insects. Mol. Nutr. Food Res. 2016, 61, 1600520. [CrossRef] [PubMed]

31. Ekop, E.A.; Udoh, A.I.; Akpan, P.E. Proximate and anti-nutrient composition of four edible insects in Awaka Ibom state, Nigeria. World J. Appl. Sci. Technol. 2010, 2, 224-231.

32. Shantibala, T.; Lokeshwari, R.K.; Debaraj, H. Nutritional and antinutritional composition of the five species of aquatic edible insects consumed in Manipur, India. J. Insect Sci. 2014, 14, 14. [CrossRef] [PubMed]

33. Buckland-Nicks, A.; Hillier, K.N.; Avery, T.S.; O'Driscoll, N. Mercury bioaccumulation in dragonflies (Odonata: Anisoptera): Examination of life stages and body regions. Environ. Toxicol. Chem. 2014, 33, 2047-2054. [CrossRef]

34. Fraqueza, M.; Patarata, L.d.C. Constraints of HACCP Application on Edible Insect for Food and Feed. In Future Foods; Mikkola, H., Ed.; Open access chapter; IntechOpen, 2017; Available online: http://dx.doi.org/10. 5772/intechopen.69300 (accessed on 31 April 2020).

35. Graczyk, H.; Knight, R.; Tamang, L. Mechanical Transmission of Human Protozoan Parasites by Insects. Clin. Microbiol. Rev. 2005, 18, 128-132. [CrossRef]

36. Libersat, F.; Kaiser, M.; Emanuel, S. Mind Control: How Parasites Manipulate Cognitive Functions in Their Insect Hosts. Front. Psychol. 2018, 9, 572. [CrossRef]

37. Braack, L.; Almeida, A.; Cornel, A.J.; Swanepoel, R.; De Jager, C. Mosquito-borne arboviruses of African origin: Review of key viruses and vectors. Parasites Vectors 2018, 11, 29. [CrossRef]

38. EFSA Scientific Committee Risk profile related to production and consumption of insects as food and feed. EFSA J. 2015, 13, 4257. [CrossRef]

39. Srinroch, C.; Srisomsap, C.; Chokchaichamnankit, D.; Punyarit, P.; Phiriyangkul, P. Identification of novel allergen in edible insect, Gryllus bimaculatus and its cross-reactivity with Macrobrachium spp. allergens. Food Chem. 2015, 184, 160-166. [CrossRef] [PubMed]

40. Ayuso, R.; Reese, G.; Leong-Kee, S.; Plante, M.; Lehrer, S.B. Molecular basis of arthropod cross-reactivity: IgE-binding cross-reactive epitopes of shrimp, house dust mite and cockroach tropomyosins. Int. Arch. Allergy Immunol. 2002, 129, 38-48. [CrossRef] [PubMed]

41. ANSES. OPINION of the French Agency for Food, Environmental and Occupational Health E Safety on "the Use of Insects as Food and Feed and the Review of Scientific Knowledge on the Health Risks Related to the Consumption of Insects"; 2014-SA-0153; ANSES: Buenos Aires, Argentina, 2015.

42. SHC, F. Food safety aspects of insects intended for human consumption (Sci Com dossier 2014/04; SHC dossier no 9160). In The FASFC's Scientific Committee and the Committee of the Superior Health Council (SHC); Superior Health Council: Brussels, Belgium, 2014.

43. Netherlands Food and Consumer Product Safety Authority. Advisory Report on the Risks Associated with the Consumption of Mass-Reared Insects; Ministry of Economic Affairs: Utrecht, The Netherlands, 15 October 2014.

44. Klunder, H.; Wolkers-Rooijackers, J.; Korpela, J.; Nout, M. Microbiological aspects of processing and storage of edible insects. Food Control. 2012, 26, 628-631. [CrossRef]

45. Megido, R.C.; Desmedt, S.; Blecker, C.; Béra, F.; Haubruge, E.; Alabi, T.A.F.; Francis, F. Microbiological Load of Edible Insects Found in Belgium. Insects 2017, 8, 12. [CrossRef] [PubMed]

46. Belluco, S.; Mantovani, A.; Ricci, A. II consumo di insetti dal punto di vista della sicurezza alimentare: Inquadramento normativo e valutazione dei rischi. In Gli Insetti: Una Risorsa Sostenibile per L'alimentazione; Atti della Accademia Nazionale Italiana di Entomologia: Firenze, Italy, 2015; pp. 21-28. ISBN 978-88-96493-14-4. 
47. House, J. Consumer acceptance of insect-based foods in the Netherlands: Academic and commercial implications. Appetite 2016, 107, 47-58. [CrossRef] [PubMed]

48. Castro, M.; Chambers, E. Willingness to eat an insect based product and impact on brand equity: A global perspective. J. Sens. Stud. 2018, 34, e12486. [CrossRef]

49. Grasso, A.; Hung, Y.; Olthof, M.R.; Verbeke, W.; A Brouwer, I. Older Consumers' Readiness to Accept Alternative, More Sustainable Protein Sources in the European Union. Nutrients 2019, 11, 1904. [CrossRef]

50. Mancini, S.; Moruzzo, R.; Riccioli, F.; Paci, G. European consumers' readiness to adopt insects as food. A review. Food Res. Int. 2019, 122, 661-678. [CrossRef]

51. Johnson, D.V. The contribution of edible forest insects to human nutrition and to forest management. In Proceedings of the A Workshop on Asia-Pacific resources and their Potential for Development, Chiang Mai, Thailand, 19-21 February 2010; Food and Agriculture Organization of the United Nations (FAO) Regional Office for Asia and the Pacific: Rome, Italy, 2010.

52. Yhoung-Aree, J.; Viwatpanich, K. Edible insects in the Laos PDR, Myanmar, Thailand, and Vietnam. 2005. Available online: https://eurekamag.com/research/004/116/004116708.php (accessed on 25 October 2019).

53. Hanboonsong, Y.; Jamjanya, T.; Durst, P. Six-legged livestock: Edible insect farming, collection and marketing in Thailand. In Food and Agriculture Organization of the United Nations (FAO); Regional Office for Asia and the Pacific: Bangkok, Thailand, 2013.

54. Ramos-Elorduy, J. Energy Supplied by Edible Insects from Mexico and their Nutritional and Ecological Importance. Ecol. Food Nutr. 2008, 47, 280-297. [CrossRef]

55. Hurd, K.J.; Shertukde, S.; Toia, T.; Trujillo, A.; Pérez, R.L.; Larom, D.L.; Love, J.J.; Liu, C. The Cultural Importance of Edible Insects in Oaxaca, Mexico. Ann. Èntomol. Soc. Am. 2019, 112, 552-559. [CrossRef]

56. Dreon, A.L.; Paoletti, M.G. The wild food (plants and insects) in western friuli local knowledge (friuli-venezia giulia, north eastern italy). Nat. Hist. 2009, 12, 461-488.

57. Megido, R.C.; Gierts, C.; Blecker, C.; Brostaux, Y.; Haubruge, É.; Alabi, T.; Francis, F. Consumer acceptance of insect-based alternative meat products in Western countries. Food Qual. Prefer. 2016, 52, 237-243. [CrossRef]

58. Tan, H.S.G.; House, J. Consumer Acceptance of Insects as Food: Integrating Psychological and Socio-cultural Perspectives. In Edible Insects in Sustainable Food Systems; Halloran, A., Flore, R., Vantomme, P., Roos, N., Eds.; Springer International Publishing: Berlin/Heidelberg, Germany, 2018; pp. 375-386.

59. Lensvelt, E.; Steenbekkers, L.P.A. Exploring Consumer Acceptance of Entomophagy: A Survey and Experiment in Australia and the Netherlands. Ecol. Food Nutr. 2014, 53, 543-561. [CrossRef]

60. Verneau, F.; La Barbera, F.; Kolle, S.; Amato, M.; Del Giudice, T.; Grunert, K. The effect of communication and implicit associations on consuming insects: An experiment in Denmark and Italy. Appetite 2016, 106, 30-36. [CrossRef] [PubMed]

61. Pambo, K.O.; Okello, J.J.; Mbeche, R.M.; Kinyuru, J.N.; Alemu, M.H. The role of product information on consumer sensory evaluation, expectations, experiences and emotions of cricket-flour-containing buns. Food Res. Int. 2018, 106, 532-541. [CrossRef]

62. Piqueras-Fiszman, B.; Kraus, A.A.; Spence, C. "Yummy" versus "Yucky"! Explicit and implicit approach-avoidance motivations towards appealing and disgusting foods. Appetite 2014, 78, 193-202. [CrossRef] [PubMed]

63. Castro, M.; Chambers, E. Consumer Avoidance of Insect Containing Foods: Primary Emotions, Perceptions and Sensory Characteristics Driving Consumers Considerations. Foods 2019, 8, 351. [CrossRef]

64. Kauppi, S.-M.; Pettersen, I.N.; Boks, C. Consumer acceptance of edible insects and design interventions as adoption strategy. Int. J. Food Des. 2019, 4, 39-62. [CrossRef]

65. Nonaka, K. Cultural and commercial roles of edible wasps in Japan. In Proceedings of the A Workshop on Asia-Pacific Resources and their Potential for Development, Chiang Mai, Thailand, 19-21 February 2010; Food and Agriculture Organization of the United Nations (FAO)—Regional Office for Asia and the Pacific: Rome, Italy, 2010.

66. Dohrmann, D.D.; Putnik, P.; Kovačević, D.B.; Simal-Gandara, J.; Lorenzo, J.; Barba, F.J. Japanese, Mediterranean and Argentinean diets and their potential roles in neurodegenerative diseases. Food Res. Int. 2019, 120, 464-477. [CrossRef]

67. Pallauf, K.; Giller, K.; Huebbe, P.; Rimbach, G. Nutrition and Healthy Ageing: Calorie Restriction or Polyphenol-Rich "MediterrAsian" Diet? Oxidative Med. Cell. Longev. 2013, 2013, 1-14. [CrossRef] 
68. Ogce, F.; Ceber, E.; Ekti, R.; Oran, N.T. Comparison of mediterranean, Western and Japanese diets and some recommendations. Asian Pac. J. Cancer Prev. 2008, 9, 351-356. [PubMed]

69. Asp, E.H. Factors affecting food decisions made by individual consumers. Food Policy 1999, 24, $287-294$. [CrossRef]

70. Ammann, J.; Hartmann, C.; Siegrist, M. Development and validation of the Food Disgust Picture Scale. Appetite 2018, 125, 367-379. [CrossRef] [PubMed]

71. Barrena, R.; Sánchez, M. Neophobia, personal consumer values and novel food acceptance. Food Qual. Prefer. 2013, 27, 72-84. [CrossRef]

72. DeRoy, O.; Reade, B.; Spence, C. The insectivore's dilemma, and how to take the West out of it. Food Qual. Prefer. 2015, 44, 44-55. [CrossRef]

73. Laureati, M.; Proserpio, C.; Jucker, C.; Savoldelli, S. New sustainable protein sources: consumers' willingness to adopt insects as feed and food. Ital. J. Food Sci. 2016, 28, 652. [CrossRef]

74. Conti, C.; Costa, A.; Balzaretti, C.M.; Russo, V.; Tedesco, D. Survey on Food Preferences of University Students: From Tradition to New Food Customs? Agriculture 2018, 8, 155. [CrossRef]

75. Balzan, S.; Fasolato, L.; Maniero, S.; Novelli, E. Edible insects and young adults in a north-east Italian city an exploratory study. Br. Food J. 2016, 118, 318-326. [CrossRef]

76. Sogari, G. Entomophagy and Italian consumers: An exploratory analysis. Prog. Nutr. 2015, 17, $311-316$. Available online: https:/www.mattioli1885journals.com/index.php/progressinnutrition/article/view/4960 (accessed on 31 March 2020).

77. Sogari, G.; Menozzi, D.; Mora, C. Exploring young foodies' knowledge and attitude regarding entomophagy: A qualitative study in Italy. Int. J. Gastron. Food Sci. 2017, 7, 16-19. [CrossRef]

78. Menozzi, D.; Sogari, G.; Veneziani, M.; Simoni, E.; Mora, C. Eating novel foods: An application of the Theory of Planned Behaviour to predict the consumption of an insect-based product. Food Qual. Prefer. 2017, 59, 27-34. [CrossRef]

79. Menozzi, D.; Sogari, G.; Veneziani, M.; Simoni, E.; Mora, C. Explaining the Intention to Consume an Insect-Based Product: A Cross-Cultural Comparison. In Theory of Planned Behavior New Research; Nova Publishers: New York, NY, USA, 2017; pp. 201-216.

80. Sogari, G.; Menozzi, D.; Mora, C. Sensory-liking Expectations and Perceptions of Processed and Unprocessed Insect Products. Int. J. Food Syst. Dyn. 2018, 9, 314-320. [CrossRef]

81. Sogari, G.; Florio, I.; Menozzi, D.; Mora, C. Uso della food neophobia scale per investigare l'intenzione di mangiare prodotti a base di insetti. Agriregionieuropa 2017, 13, 51.

82. Mancini, S.; Sogari, G.; Menozzi, D.; Nuvoloni, R.; Torracca, B.; Moruzzo, R.; Paci, G. Factors Predicting the Intention of Eating an Insect-Based Product. Foods 2019, 8, 270. [CrossRef] [PubMed]

83. Cicatiello, C.; De Rosa, B.; Franco, S.; Lacetera, N. Consumer approach to insects as food: Barriers and potential for consumption in Italy. Br. Food J. 2016, 118, 2271-2286. [CrossRef]

84. La Barbera, F.; Verneau, F.; Amato, M.; Grunert, K. Understanding Westerners' disgust for the eating of insects: The role of food neophobia and implicit associations. Food Qual. Prefer. 2018, 64, 120-125. [CrossRef]

85. Lombardi, A.; Vecchio, R.; Borrello, M.; Caracciolo, F.; Cembalo, L. Willingness to pay for insect-based food: The role of information and carrier. Food Qual. Prefer. 2019, 72, 177-187. [CrossRef]

86. Materia, V.; Cavallo, C. Insetti per l'alimentazione umana: Barriere e drivers per l'accettazione da parte dei consumatori. Ital. Rev. Agric. Econ. 2015, 70, 139-161. [CrossRef]

87. Materia, V.C.; Cavallo, C. Insects or not Insects? Dilemmas or Attraction for Young Generations: A Case in Italy. Int. J. Food Syst. Dyn. 2018, 9, 226-239. [CrossRef]

88. La Barbera, F.; Verneau, F.; Videbæk, P.N.; Amato, M.; Grunert, K.G. A self-report measure of attitudes toward the eating of insects: Construction and validation of the Entomophagy Attitude Questionnaire. Food Qual. Prefer. 2020, 79, 103757. [CrossRef]

89. Lowenberg, M.E. Socio-cultural basis of food habits. Food Technol. 1970, 24, 27-32.

90. Di Renzo, E. Oltre l'edibile: Su alcune valenze antropologico-culturali del cibo. Econ. Della Cult. 2010, 20, 57-66.

91. Briggs, A. Sugar tax could sweeten a market failure. Nature 2016, 531, 551. [CrossRef] [PubMed]

92. Boccia, F.; Covino, D.; Sarnacchiaro, P. Genetically modified food versus knowledge and fear: A Noumenic approach for consumer behaviour. Food Res. Int. 2018, 111, 682-688. [CrossRef] 
93. Mauracher, C.; Tempesta, T.; Vecchiato, D. Consumer preferences regarding the introduction of new organic products. The case of the Mediterranean sea bass (Dicentrarchus labrax) in Italy. Appetite 2013, 63, 84-91. [CrossRef]

94. Cosmina, M.; Gallenti, G.; Marangon, F.; Troiano, S. Attitudes towards honey among Italian consumers: A choice experiment approach. Appetite 2016, 99, 52-58. [CrossRef]

95. Scozzafava, G.; Corsi, A.M.; Casini, L.; Contini, C.; Loose, S.M. Using the animal to the last bit: Consumer preferences for different beef cuts. Appetite 2016, 96, 70-79. [CrossRef]

96. Mancini, M.C.; Antonioli, F. Exploring consumers' attitude towards cultured meat in Italy. Meat Sci. 2019, 150, 101-110. [CrossRef]

(C) 2020 by the authors. Licensee MDPI, Basel, Switzerland. This article is an open access article distributed under the terms and conditions of the Creative Commons Attribution (CC BY) license (http://creativecommons.org/licenses/by/4.0/). 